\title{
Combining ability studies in tropical sorghum (Sorghum bicolor (L.) Moench)
}

\author{
R. Kenga ${ }^{\mathrm{a}, *}$, S.O. Alabi ${ }^{\mathrm{b}}$, S.C. Gupta ${ }^{\mathrm{c}, 1}$ \\ ${ }^{a}$ Institute of Agronomic Research for Development (IRAD), Box 33, Maroua, Cameroon \\ ${ }^{\mathrm{b}}$ Department of Plant Science/IAR, Ahmadu Bello University, Zaria, Nigeria \\ ${ }^{\mathrm{c}}$ ICRISAT, Kano, Nigeria
}

Received 3 August 2003; received in revised form 1 January 2004; accepted 10 January 2004

\begin{abstract}
Sorghum varieties grown in West Africa usually have low production potential. Information on combining ability of diverse open-pollinated cultivars and gene pools is needed for efficient choice of breeding methods and parental materials to use in developing breeding programs to increase production. Twenty parental lines including 15 restorers and 5 male-sterile A-lines were mated. The 20 parents were sampled from elite germplasm available for cultivar development in the region. Combining ability studies were conducted on these parents along with their $F_{1}$ hybrids for grain yield, days to anthesis, plant height, inflorescence length, threshing percentage, and seed mass in 2 years and in two locations. Each location-year combination was considered as an environment. For each trait, general combining ability (GCA) and specific combining ability (SCA) effects were estimated using the line-tester method of analysis. Highly significant GCA effects of males were found for all traits under study. Significant SCA was detected in all traits except inflorescence length. From the ratio of general combining ability to specific combining ability non-additive gene action was predominant for most traits. Parental lines with good performance per se and good performance in crosses for most agronomic traits included: ICSA 902 NG, NR 71182-2, NR 71182-3, CS 144, and Damougari. Both additive and non-additive gene effects are involved in variations observed among crosses. Hybrid breeding could contribute to sorghum improvement in the dry land agriculture of West Africa. Importance of genotype-environment interaction underlines the necessity of evaluating breeding materials under broad range of conditions. The various traits studied can be improved through breeding procedures using a range of different intra-population and inter-population selection procedures. In hybrid breeding procedures, testing of parent lines for general combining ability should be supplemented by evaluation of individual $F_{1}$ hybrids for specific combining ability.
\end{abstract}

(C) 2004 Elsevier B.V. All rights reserved.

Keywords: Combining ability; Hybrid breeding; Sorghum bicolor; Tropical landrace

\footnotetext{
* Corresponding author. Tel.: +237-29-34-62; fax: $+237-29-24-15$.

E-mail addresses: rckenga@yahoo.com (R. Kenga), sooalabi@yahoo.com (S.O. Alabi), scgupta50@yahoo.com (S.C. Gupta).

${ }^{1}$ Present address: ICRISAT, NASC Complex, Pusa, New Delhi 110012, India.
}

\section{Introduction}

Sorghum (Sorghum bicolor (L.) Moench) is a major cereal in the semi-arid regions of the world where it is an important food and feed crop. It can also be used as raw material for industry and can be processed into malted foods, beverages and beer 
(Palmer, 1992). In the western hemisphere, sorghum is primarily grown as livestock feed. Presently, it is the third important cereal grown in the US (Shantharam, 1995). In the dry land agriculture of West Africa, abiotic and biotic stresses limit potential grain yield. Even though several improved varieties have been developed and released, yield gains at farmers' level are minimal with average yields that are still approximately $850 \mathrm{~kg} \mathrm{ha}^{-1}$ only (FAO, 1997). Improvement of sorghum by selection within traditional cultivars or by selecting progeny from crosses between similar traditional cultivars has generally not been promising in enhancing yields (House, 1995). The demand for cereals in this region calls for an increase in the production of sorghum, and must come mainly from increased yield per unit area.

Developing high yielding and adapted hybrid sorghum is one approach to resolving cereal grain deficits. In the last 20 years, the area of sorghum harvested in Africa has nearly doubled, but average yield has not increased. By contrast, in India during the same period sorghum area has declined 37\%, but yields have increased by $80 \%$ (USDA, 1997). Hybrid use, and a consequent increase in genetic research has been a major factor in the yield increases recorded in India. Hybrids offer some advantages over pure line varieties in that complementary traits from parental lines can be combined in a single $F_{1}$ genotype with resulting adaptation to different stress environments. In addition, hybrids offer some incentive to private sector involvement in cultivars development because hybrids are proprietary and producers purchase seeds every season.

In recent years, several national research programs in the semi-arid regions have shown an increased interest in hybrids (Axtell et al., 1999). The immediate task that faced those breeding programs is to gain information on the combining ability of the various varieties and populations developed and improved over the years. Information on combining ability is needed to identify potentially superior parents and hybrids, and would also help to define the pattern of gene effects in the expression of quantitative traits (Goyal and Kumar, 1991). The general combining ability (GCA) of each parent should be examined when the objective is the development of superior genotypes, while the specific combining ability (SCA) effects provide information about the performance of hybrids (Cruz and Regazzi, 1994). The differences in GCA are mainly due to the additive genetic effects and higher order additive interactions, while the differences in SCA are attributed to the non-additive dominance and other types of epitasis (Falconer, 1989). This analysis therefore allows broad inferences on the nature of the gene effects for a trait under selection. The breeder can make use of this information to find the best strategy to select desirable parents or determine which breeding procedure will efficiently improve the performance of the traits of interest (Dudley and Moll, 1969).

During the course of hybrid sorghum development, it was expected that the already well-adapted African sorghum landraces would furnish greater pollinators, but the successful high yielding hybrids have been obtained from exotic parents. Sorghum breeders in tropics have relied heavily on the genetic diversity within local germplasm for selecting open-pollinated varieties and have only occasionally attempted to characterize the heterotic patterns and combining ability of the varieties or populations developed. This is primarily due to slow growing interest in hybrids among national programs and lack of a viable private sector seed industry. Today, consideration of food security and socio-economic equity demand that feasible technologies that will increase cereal yield should be adopted. Information on combining ability studies is limited (Paisan and Atkins, 1977; Beil and Atkins, 1967; Malm, 1968). These evaluations were carried out in temperate environments with the materials obtained from a successful photoperiod conversion program (Maunder, 1992). There is currently a paucity of information on combining ability involving well-adapted genotypes under African dry land sorghum growing conditions. This information is vital to decisions regarding the commitment of breeding resources to develop and evaluate efficient methods of producing commercial $\mathrm{F}_{1}$ hybrids. Parents that will contribute favorable combination of genes for yield and other agronomic traits are the most sought.

The objective of this study was to assess the combining ability of selected tropical sorghum landraces, aiming to a parental selection and germplasm improvement for breeding programs to increase production. 


\section{Materials and methods}

\subsection{Hybrids development}

Five cytoplasmic genetic male-sterile lines (ATX 623, ICSA 38, ICSA 39, ICSA 41 and ICSA 902 NG) used as females (A-lines) were crossed on to each of the 15 pollen restorer male-fertile parents to produce $75 \mathrm{~F}_{1}$ hybrids. The 15 male parents were selected from different origins and representing the elite varieties commonly grown in West and Central Africa. The male parents included eight lines (NR 71176-1, NR 71176-2, NR 71182-2, NR 71182-3, NR 71168-1, NR 71168-3, KSV 4-1, KSV 4-2) obtained by induced mutation on four varieties of the Fara-Fara group, and seven varieties of durra and Caudatum types. The check varieties were three open-pollinated varieties (CS 210, CS 54, CS 133) and two landraces (Zouaye and Djigari) from different sorghum breeding programs of West and Central Africa. The male-sterile lines were Kafir-milo derivatives and have the same cytosterile mechanism.

\subsection{Site characteristics}

A trial which consisted of 100 sorghum entries including $75 \mathrm{~F}_{1}$ hybrids, 15 restorer-lines, five B-lines and five checks was conducted in 2 years (1998 and 1999 rainy seasons) and in two locations. The first location was at the Institute of Agricultural Research for Development (IRAD) research farm (latitude $11^{\circ} 30^{\prime} \mathrm{N}$, longitude $15^{\circ} 30^{\prime} \mathrm{E}$, altitude $300 \mathrm{~m}$ ) at Maroua in Cameroon. The vegetation in the area around Maroua is typical of the Sudano Sahelien zone (Windmeijer and Andriesse, 1993). Mean total annual rainfall is approximately $750 \mathrm{~mm}$ and the length of the growing period is 120-150 days with frequent drought. Rainfall during the 2-year trial (Table 1) was irregular. The soil at Maroua is sandy, siliceous reddish colored, low in fertility and organic matter. The second location was at the International Crops Research Institute for Semi-Arid Tropics (ICRISAT) research farm (latitude $11^{\circ} 53^{\prime} \mathrm{N}$, longitude $8^{\circ} 14^{\prime} \mathrm{E}$, altitude $440 \mathrm{~m}$ ) at Bagauda in Nigeria. Average annual total rainfall is approximately $900 \mathrm{~mm}$ and the length of growing period is 140-160 days. The landscape is flat and dissected by low to medium density of in land valleys typical of the Sudano Savanna zone on plinthic luvisol with average depth of $90 \mathrm{~cm}$ (Windmeijer and Andriesse, 1993).

\subsection{Field experiment}

The 100 entries were arranged in a $10 \times 10$ triple lattice design. The experiment was replicated three times at each location. Each plot consisted of four rows; $5 \mathrm{~m}$ long with $80 \mathrm{~cm}$ between rows, resulting in a total plot area of $16 \mathrm{~m}^{2}$. The experiment was hand planted. All rows were thinned to $20 \mathrm{~cm}$ between hills at two plants per hill, resulting in a population of about 130000 plants per hectare. Standard cultural practices for optimum sorghum production were carried out at each location. The same dose of fertilizer (60 kg ha ${ }^{-1} \mathrm{~N}: 40 \mathrm{~kg} \mathrm{ha}^{-1} \mathrm{P}_{2} \mathrm{O}_{5}: 30 \mathrm{~kg} \mathrm{ha}^{-1} \mathrm{~K}_{2} \mathrm{O}$ ) was applied as a basal dose in each experiment, with a further $40 \mathrm{~kg}$ of nitrogen per hectare in the form of urea top-dressed 5 weeks after planting and then incorporated into the soil. The number of days to anthesis, inflorescence length, plant height, grain yield, seed mass and threshing percentage were recorded according to the International Board for Plant Genetic Resources (IBPGR) and ICRISAT descriptor list for sorghum (IBPGR/ICRISAT, 1993). The number of days to anthesis, and threshing percentage were assessed on a whole plot basis. Plant height and inflorescence length were taken from the

Table 1

Description of environment with total rainfall in crop season, and environmental mean for grain yield average over 100 genotypes grown in each environment

\begin{tabular}{llllll}
\hline Environment & Year & Location & Planting date & Rainfall $(\mathrm{mm})$ & Environmental mean yields $\left(\mathrm{t}\right.$ ha $\left.^{-1}\right)$ \\
\hline 1 & 1998 & Maroua & 5 July & 675 & 2.43 \\
2 & 1998 & Bagauda & 18 June & 930 & 3.10 \\
3 & 1999 & Maroua & 12 July & 775 & 1.54 \\
4 & 1999 & Bagauda & 12 June & 980 & 3.60 \\
\hline
\end{tabular}


two central rows of each plot on five randomly selected plants. At maturity, panicles in the two central rows were cut, sun-dried and threshed to determine the grain yield per plot. Seed mass in each plot was obtained by weighing 1000 seeds counted using a numeral electrical seed counter.

\subsection{Statistical procedure}

All statistical analyses were performed using PROC GLM procedures (SAS Institute, 1989). Each location-year combination was considered as an environment. Analyses of variance were conducted for the various traits measured using individual plot data (not adjusted for lattice block effects) for each environment. Each of the four environments was first analyzed separately (data not shown) then a combined analysis across environments based on the following linear additive model was performed:

$Y_{i j k r}=\mu+G_{i}+E_{j}+(\mathrm{GE})_{i j}+R_{j k}+\mathrm{Bl}_{j r} e_{i j k r}$

where $Y_{i j k}$ is the observation of any variable in the $r$ th replication in the $k$ th block in the $j$ th environment (Env) of the $i$ th genotypes, $\mu$ the general mean; $G_{i}$ and $E_{j}$ represent the effects of the $i$ th genotype and $j$ th environment, while $(\mathrm{GE})_{i j}$ stands for the genotypeenvironment interactions, $R_{j k}$ for the replication effect of the $k$ th block at the $j$ th environment, $\mathrm{Bl}_{j r}$ for the block effect of the $r$ th replication at the $j$ th environment, while $e_{i j k r}$ designates the random errors associated with the $r$ th replication of $i$ th genotypes at the $j$ th environment in the $k$ th block $(i=1,2, \ldots, 100 ; j=$ $1,2,3,4 ; r=1,2,3 ; k=1,2, \ldots, 10)$.

Environments were considered as random effects and entries were considered as random, representing the current pool of elite hybrids, varieties and genotypes in the region. Entry main effect and their interactions were partitioned into various components: parent, hybrids, parent versus hybrids, checks, environment-parent, environment-hybrids, environmenthybrids versus parent, environment-checks, environment-checks versus rest.

The $F$-tests for ANOVA were calculated as follows. Main effects, such as entries and its partitions were tested against their respective interaction with environment where the interaction means squares were significant, and all the interaction terms were tested against the error mean squares.

\subsection{Combining ability}

Analysis of variance for combining ability was carried out using mean values across environments following the procedure of Kempthorne (1957) related to the method of Comstock and Robinson (1952). The sum of squares for hybrids was further partitioned into variation due to lines, testers and lines-testers interactions. The mean squares due to lines and testers were tested against the mean squares due to linetester, and the latter were tested against the pooled error. The mean squares due to environment-line and environment-tester were tested against the mean squares due to environment-tester-line, and the latter was tested against the pooled error. Standard errors for GCA effects of females (lines) and males (testers) and the SCA effects were calculated using the method described by Cox and Frey (1984). Two-tailed $t$-tests were used to test the significance of the GCA and SCA effects. Estimate of GCA variances $\left(\delta_{\mathrm{GCA}}^{2}\right)$ and SCA variances $\left(\delta_{\mathrm{SCA}}^{2}\right)$ were obtained as suggested by Singh and Chaudhary (1977). Ratios of mean square components associated with variance of GCA and SCA effects were computed as suggested by Baker (1978) to estimate the relative importance of GCA in explaining performance. The closer the ratio is to unity, the greater the predictability of progeny performance based on GCA effects alone.

\section{Results and discussion}

Coefficients of variation were $<13 \%$ for individual environments (data not shown) for most traits studied. Combined analyses of variance for six agronomic traits measured over the four environments are presented in Table 2. The mean squares due to environment, entries and environment-entries interactions were significant, indicating the diversity of the genotypes and their differences in environmental response. Partitioning of the entries mean squares into variations attributable to parents, hybrids and checks showed that variation within each group with environment was significant for most of the traits. Consequently, it was necessary to carry out experiments in various environments to obtain a reliable assessment of the main effects. The mean squares due to male versus female were highly significant for all traits, indicating a wide 
Table 2

Mean squares from the combined analysis of variances for the six traits measured across environments

\begin{tabular}{|c|c|c|c|c|c|c|c|}
\hline Sources of variation & d.f. & $\begin{array}{l}\text { Grain yield } \\
\left(\mathrm{kg} \mathrm{ha}^{-1}\right)\end{array}$ & $\begin{array}{l}\text { Days to } \\
\text { anthesis }\end{array}$ & $\begin{array}{l}\text { Plant } \\
\text { height }(\mathrm{cm})\end{array}$ & $\begin{array}{l}\text { Inflorescence } \\
\text { length }(\mathrm{cm})\end{array}$ & $\begin{array}{l}\text { Threshing } \\
(\%)\end{array}$ & $\begin{array}{l}\text { Seed } \\
\text { mass }(g)\end{array}$ \\
\hline Environment (Env) & 3 & $237788072^{*}$ & $4248^{*}$ & $221886^{*}$ & $783^{*}$ & $7052^{*}$ & $9613^{*}$ \\
\hline Replication/Env & 8 & 13557869 & 118 & 6035 & 82 & 369 & 61 \\
\hline Block $(\operatorname{Rep} \times$ Env $)$ & 108 & 1632501 & 25 & 696 & 15 & 79 & 9 \\
\hline Entry & 99 & $3007949^{*}$ & $68^{*}$ & $30257^{*}$ & $188^{*}$ & $176^{*}$ & $50^{*}$ \\
\hline Parents & 19 & $2678009^{*}$ & $49^{*}$ & $13111^{*}$ & $229^{*}$ & $371^{*}$ & $95^{*}$ \\
\hline Male & 14 & $2659767^{*}$ & $89^{*}$ & $21607^{*}$ & $180^{*}$ & $367^{*}$ & $74^{*}$ \\
\hline Female & 4 & 73782 & $18^{*}$ & $1569^{*}$ & $129^{*}$ & $136^{*}$ & 11 \\
\hline Male vs. female & 1 & $12541388^{*}$ & $178^{*}$ & $60077^{*}$ & $2386^{*}$ & $2346^{*}$ & $1107^{*}$ \\
\hline Hybrids & 74 & $2195041^{*}$ & $67^{*}$ & $25452^{*}$ & $104^{*}$ & $116^{*}$ & $28^{*}$ \\
\hline Parents vs. hybrids & 1 & $72278052^{*}$ & $58^{* *}$ & $635887^{*}$ & $3205^{*}$ & 183 & 7 \\
\hline Checks & 4 & 742603 & 101 & $5921^{*}$ & $117^{*}$ & 85 & $64^{*}$ \\
\hline Checks vs. rest & 1 & 2789043 & 11 & 2563 & 1655 & 230 & $180^{*}$ \\
\hline Env-entry & 297 & $1240452^{*}$ & $23^{*}$ & $1164^{*}$ & $18^{*}$ & $103^{*}$ & $14^{*}$ \\
\hline Env-parents & 57 & 555808 & $16^{*}$ & $582^{*}$ & $23^{*}$ & 86 & 9 \\
\hline Env-male & 42 & $979347^{* *}$ & $22^{*}$ & $780^{*}$ & $22^{* *}$ & 93 & $11^{* *}$ \\
\hline Env-female & 12 & 482598 & 6 & 278 & 18 & 102 & 16 \\
\hline Env-male vs. female & 3 & 1125868 & 29 & 635 & 46 & 155 & 14 \\
\hline Env-hybrids & 222 & $1300398^{*}$ & $17^{*}$ & $1286^{*}$ & $15^{*}$ & $99^{*}$ & $12^{*}$ \\
\hline Env-hybrids vs. parent & 3 & $5347823^{*}$ & 63 & 3792 & 40 & 205 & $38^{*}$ \\
\hline Env-checks & 12 & $1295473^{* *}$ & 117 & 1066 & $40^{*}$ & $138^{* * *}$ & $60^{*}$ \\
\hline Env-checks vs. rest & 3 & 1369650 & $55^{* *}$ & 1066 & 34 & 93 & $40^{* * *}$ \\
\hline Error & 684 & 661111 & 11 & 567 & 11 & 61 & 8 \\
\hline
\end{tabular}

* Significant at 0.01 probability levels.

** Significant at 0.05 probability levels.

range of variation within the male and the female parents. Similarly, mean square value due to parents versus hybrids were significant for grain yield, days to anthesis, plant height and inflorescence length, suggesting that there were high heterotic responses for these traits.

Analyses of variance for combining ability along with estimates of variances for combining ability are presented in Table 3. The mean squares due to GCA of the tester were significant for all traits. The SCA mean squares were also significant, except for inflorescence length indicating the importance of additive gene effects as the main cause of the observed genetic variation for inflorescence length. The significance of GCA and SCA for grain yields, days to anthesis, plant height, threshing percentage, and seed weight showed the importance of both the additive and nonadditive gene effects. Furthermore, significant interactions were found between the environment and GCA of lines for threshing percentage and seed weight, and also between the environment and GCA of testers for days to anthesis, inflorescences length, threshing percentage and seed weight. This confirms the differences of genotypes in environment responses for these traits. The significant hybrid-environment and SCA-environment for plant height may have been caused by differential rainfall pattern and length of growing period at the four environments, which could have had differential effects on hybrids of different maturities.

The importance of the source of variation is indicated by the relative magnitude of variance components. The variance component estimates of SCA were greater than that of GCA for grain yield, days to anthesis, plant height, inflorescence length, threshing percentage and seed weight (Table 3 ). In addition, the ratio of the mean square components associated with variance of GCA and SCA was much less than the theoretical maximum of unity for all traits studies. These results tend to suggest that genetic variation among crosses was primarily of the non-additive type. In addition, the highly significant variance due to 
Table 3

Mean squares from analysis of variances for combining ability for six traits measured across four environments

\begin{tabular}{|c|c|c|c|c|c|c|c|}
\hline Sources of variation & d.f. & $\begin{array}{l}\text { Grain yield } \\
\left(\mathrm{kg} \mathrm{ha}^{-1}\right)\end{array}$ & $\begin{array}{l}\text { Days to } \\
\text { anthesis }\end{array}$ & $\begin{array}{l}\text { Plant } \\
\text { height }(\mathrm{cm})\end{array}$ & $\begin{array}{l}\text { Inflorescence } \\
\text { length }(\mathrm{cm})\end{array}$ & $\begin{array}{l}\text { Threshing } \\
(\%)\end{array}$ & $\begin{array}{l}\text { Seed } \\
\text { mass }(g)\end{array}$ \\
\hline Lines (GCA) & 4 & 1930150.78 & $157.55^{*}$ & 3011.25 & 68.81 & $239.30^{* *}$ & $171.72^{*}$ \\
\hline Tester (GCA) & 14 & $5571903.53^{*}$ & $216.10^{*}$ & $121640.5^{*}$ & $475.90^{*}$ & $195.08^{* * *}$ & $45.87^{*}$ \\
\hline Line-tester (SCA) & 56 & $1387265.32^{*}$ & $19.63^{*}$ & $2237.91^{*}$ & 12.70 & $88.33^{* * *}$ & $13.90^{*}$ \\
\hline Env-line & 12 & 190764.85 & 10.91 & 905.54 & 14.02 & $240.01^{*}$ & $20.67^{*}$ \\
\hline Env-tester & 42 & 2321227.90 & $45.86^{*}$ & 1343.30 & $42.24^{*}$ & $175.30^{*}$ & $29.37^{*}$ \\
\hline Env-line-tester & 168 & 987991.16 & 11.57 & $1297.67^{*}$ & 8.94 & 70.07 & 8.09 \\
\hline Error & 592 & 2412476.00 & 27.19 & 1303.55 & 25.57 & 137.88 & 18.65 \\
\hline \multicolumn{8}{|c|}{ Variance component estimates } \\
\hline Lines & & 39648.0 & 0.373 & 158.0 & 0.510 & 0.846 & 0.108 \\
\hline Tester & & 13541.0 & 1.042 & 1674.0 & 5.162 & -0.672 & 1.516 \\
\hline$\delta_{\mathrm{GCA}}^{2}$ & & 611.5 & 0.540 & 537.03 & 1.673 & 0.466 & 0.460 \\
\hline$\delta_{\mathrm{SCA}}^{2}$ & & 117800 & 4.314 & 592.9 & 3.611 & 5.472 & 0.480 \\
\hline$\delta_{\mathrm{GCA}}^{2 \mathrm{~A}} / \delta_{\mathrm{SCA}}^{2}$ & & 0.0052 & 0.125 & 0.906 & 0.463 & 0.085 & 0.958 \\
\hline \multicolumn{8}{|c|}{ Proportional contribution to total variances } \\
\hline Lines & & 20.14 & 9.05 & 6.92 & 6.69 & 11.75 & 5.61 \\
\hline Testers & & 11.12 & 30.53 & 72.36 & 58.14 & 12.92 & 60.56 \\
\hline Line-tester & & 68.74 & 60.42 & 20.72 & 35.17 & 75.33 & 33.83 \\
\hline
\end{tabular}

* Significant at 0.01 probability levels.

*** Significant at 0.05 probability levels.

parent versus hybrid (Table 2), which is a measure of average heterosis, also points to the importance of non-additive genetic effect in determining grain yield, plant height, inflorescence length in these germplasm. Most workers (Beil and Atkins, 1967; Kirby and Atkins, 1968) have reported that additive gene effects were a predominant factor determining grain yield in sorghum. On the other hand, Liang and Walter (1968) found that both additive and non-additive gene effects were important in determining grain yield in sorghum. Kirby and Atkins (1968) observed in their materials that additive gene action played a major role in the inheritance of seed mass, while Niehaus and Pickett (1966) observed that both additive and non-additive gene effects were important in the expression of this trait. These authors used genotypes obtained from a successful photoperiod conversion program for tropical sorghum, in which accessions were crossed to a photoperiod-insensitive inbred and the less photoperiod sensitive progeny in the segregating population were selected for backcrossing to the accession (Maunder, 1992), while the present study focused on tropical landraces and elite lines. This might explain the significant variation among crosses for SCA. However, it was earlier indicated that significant
GCA effects detected for grain yield, days to anthesis, plant height, and inflorescence length also implied the contribution of additive gene effects to the variation expressed among hybrids.

Rojas and Sprague (1952) reported that the variances for specific combining ability effects became relatively more important than the variance for general combining ability effects when the lines used under tests had been subjected to previous testing and selections. The male lines used in this study represent a wide range of different sorghum genotypes cultivated in the sub-region. They probably have been highly selected for traits of economic importance, therefore a high level of male-female interaction may be expected.

The selection of parental lines for hybrid programs was one of the objectives of this study. Thus, the estimates of the general combining ability $\left(g_{i}\right)$ of a parent provide important indicators of its potential for generating superior lines. A low $g_{i}$ estimate, whether positive or negative, indicates that the mean of a parent in crossing with the other, does not differ greatly from the general mean of the crosses. On the other hand, a high $g_{i}$ estimate indicates that the parental mean is superior or inferior to the general mean. This gives 
Table 4

Estimates of general combining ability effects of parent lines for different traits across four environments

\begin{tabular}{|c|c|c|c|c|c|c|}
\hline Parental line & $\begin{array}{l}\text { Grain yield } \\
\left(\mathrm{kg} \mathrm{ha}^{-1}\right)\end{array}$ & $\begin{array}{l}\text { Days to } \\
\text { anthesis }\end{array}$ & $\begin{array}{l}\text { Plant } \\
\text { height }(\mathrm{cm})\end{array}$ & $\begin{array}{l}\text { Inflorescence } \\
\text { length }(\mathrm{cm})\end{array}$ & $\begin{array}{l}\text { Threshing } \\
(\%)\end{array}$ & $\begin{array}{l}\text { Seed } \\
\text { mass }(\mathrm{g})\end{array}$ \\
\hline \multicolumn{7}{|l|}{ Lines } \\
\hline ATX 623 & $-164.3^{*}$ & -0.2644 & $-22.787^{* *}$ & $1.2052^{* *}$ & 0.3276 & $-0.4490^{*}$ \\
\hline ICSA 38 & 24.3 & -0.3811 & 1.467 & -0.0048 & -0.9802 & -0.1529 \\
\hline ICSA 39 & -119.1 & $-0.8089^{* *}$ & -2.020 & -0.1837 & -0.6287 & 0.0282 \\
\hline ICSA 41 & -129.6 & $1.4078^{* *}$ & $13.454^{* * *}$ & 0.2863 & -0.7662 & -0.1440 \\
\hline ICSA $902 N G$ & $388.8^{* * *}$ & 0.0467 & $9.887^{* *}$ & -1.3031 & $2.0474^{* * *}$ & $0.7172^{* *}$ \\
\hline S.E. $\left(g_{i}\right)$ & 70.21 & 0.2291 & 1.873 & 0.2565 & 0.5916 & 0.2236 \\
\hline S.E. $\left(g_{i}-g_{j}\right)$ & 99.30 & 0.3240 & 2.649 & 0.3627 & 0.8366 & 0.3163 \\
\hline \multicolumn{7}{|l|}{ Testers } \\
\hline NR 71176-1 & 191.5 & $-1.176^{* *}$ & $-40.59^{* *}$ & $2.326^{* *}$ & 1.6761 & $2.3143^{* *}$ \\
\hline NR 71176-2 & -103.7 & -0.442 & $8.26^{*}$ & $-1.699^{* *}$ & 1.4346 & 0.4843 \\
\hline NR 71182-2 & $258.7^{*}$ & $-0.926^{*}$ & $47.48^{* *}$ & $-2.284^{* *}$ & 1.1226 & $2.2777^{* *}$ \\
\hline NR 71182-3 & 54.7 & -0.542 & $-54.61^{* *}$ & $2.968^{* *}$ & 1.2564 & $-0.9907^{*}$ \\
\hline NR 71168-1 & 41.0 & 0.541 & $13.30^{* *}$ & $-1.610^{* *}$ & -0.8266 & -0.6373 \\
\hline NR 71168-3 & -238.0 & $2.674^{* *}$ & $50.08^{* *}$ & $-1.625^{* *}$ & -0.2386 & -0.0123 \\
\hline KSV 4-1 & $-256.3^{*}$ & 0.424 & $-66.73^{* *}$ & $2.303^{* *}$ & -1.8604 & $-2.3707^{* *}$ \\
\hline KSV 4-2 & -142.6 & $1.258^{* *}$ & -1.29 & -0.644 & -0.2419 & $-0.9890^{*}$ \\
\hline S 35 & -11.9 & $2.291^{* *}$ & $48.79^{* *}$ & $-2.369^{* *}$ & 0.3114 & -0.0990 \\
\hline CS 54 & -177.9 & $-1.809^{* *}$ & $-52.58^{* *}$ & $2.601^{* *}$ & 0.1609 & 0.2043 \\
\hline CS 61 & -13.7 & $-1.742^{* *}$ & 7.20 & $-1.095^{*}$ & 1.6949 & $1.3143^{*}$ \\
\hline CS 95 & 5.2 & 0.674 & $36.11^{* *}$ & $-2.897^{* *}$ & 1.0111 & 0.6260 \\
\hline CS 141 & 97.7 & $-1.542^{* *}$ & $-53.29^{* *}$ & $5.150^{* *}$ & -0.4362 & $-1.8923^{* * *}$ \\
\hline CS 144 & 163.5 & $-0.959^{* *}$ & $20.62^{* *}$ & 0.610 & -2.0414 & -0.3690 \\
\hline Damougari & 131.7 & $1.274^{* *}$ & $37.24^{* *}$ & $-1.735^{* *}$ & -0.5104 & 0.1393 \\
\hline S.E. $\left(g_{i}\right)$ & 121.6 & 0.3968 & 3.245 & 0.4443 & 1.025 & 0.3873 \\
\hline S.E. $\left(g_{i}-g_{j}\right)$ & 172.0 & 0.5612 & 4.589 & 0.6283 & 1.449 & 0.5478 \\
\hline
\end{tabular}

* Significant at 0.05 probability levels.

*** Significant at 0.01 probability levels.

information about the concentration of predominant genes with additive effects (Cruz and Regazzi, 1994). Estimates of GCA effects for grain yield, days to anthesis, plant height, and inflorescence length, threshing percentage and seed weight for the twenty parents used in this study are presented in Table 4 . The female ICSA 902 NG was the best general combiner for grain yield, threshing percentage, seed weight and tallness with highly significant and positive GCA effects. On the other hand, the female ATX 623 showed significant and negative GCA effects for grain yield, plant height, and seed mass. It is, however, a good combiner for dwarf stature and inflorescence length. The female ICSA 39 was a good combiner for early flowering but showed no significant GCA effect for grain yield, while ICSA 41 was a good combiner for lateness with highly significant and positive GCA effect for days to anthesis. It might produce tall hybrids with fairly low yield potential. The female ICSA 38 showed no significant effect for grain yield and plant height.

Among the male parents, the testers NR 71182-2 was the best combiner for grain yield, early flowering, seed weight, inflorescence length, and tallness with significant GCA effects. It may be used to develop high yielding, early maturing, and tall hybrids with short inflorescence length. The tester NR 71176-1 had no significant GCA estimates for grain yield, highly significant and positive GCA for inflorescence length and significant negative GCA estimates for days to anthesis and plant height. This offers greater scope in developing high yielding, early maturing and short to medium height hybrids with long inflorescences. The tester CS 144 showed 
highly significant and positive GCA estimates for plant height, highly significant and negative GCA estimate for days to anthesis and no significant GCA estimate for grain yield. It may be used to develop early maturing and tall hybrids but with low yield potential. Damougari may also be useful in developing tall and late maturing hybrids with high yield potential. The testers KSV 4-1, KSV 4-2, NR 711762, NR 71168-3, CS 54 improved one or two of the characters under study, but as they had negative effect on the remaining characters, their breeding value for hybrid production was rather low.

A comparison of GCA effects of individual lines for grain yield showed that much of the positive GCA obtained was contributed by ICSA 902 NG, NR 71182-2, NR 71176-1, CS 144, and Damougari in all test environments. This suggests a wide adaptation and high potential of these lines for use as a parent in developing well-adapted hybrid with high yield potential.

Considering the material used in this study, parents that showed negative GCA for both grain yield and seed weight probably should not be hybridized inter se, since genetic gain would not be expected for these traits in these materials, due to insufficient additive genetic variances.

The estimates of $s_{i j}$ (SCA) provide important information about the hybrid performance as related to its

Table 5

Estimates of specific combining ability effects of selected crosses for different traits, across four environments

\begin{tabular}{|c|c|c|c|c|c|c|}
\hline Hybrids crosses & $\begin{array}{l}\text { Grain yield } \\
\left(\mathrm{kg} \mathrm{ha}^{-1}\right)\end{array}$ & $\begin{array}{l}\text { Days to } \\
\text { anthesis }\end{array}$ & $\begin{array}{l}\text { Plant } \\
\text { height }(\mathrm{cm})\end{array}$ & $\begin{array}{l}\text { Inflorescence } \\
\text { length }(\mathrm{cm})\end{array}$ & $\begin{array}{l}\text { Threshing } \\
(\%)\end{array}$ & $\begin{array}{l}\text { Seed } \\
\text { mass (g) }\end{array}$ \\
\hline \multicolumn{7}{|l|}{ ATX $623 \times$} \\
\hline NR 71176-1 & 291.4 & 0.464 & $23.26^{*}$ & -0.977 & 0.785 & -0.5593 \\
\hline NR 71176-2 & 254.4 & 0.248 & $16.23^{* *}$ & 0.916 & 0.109 & -0.9638 \\
\hline CS 54 & 144.4 & $1.920^{* *}$ & $14.93^{* *}$ & 0.165 & 1.024 & $2.5273^{*}$ \\
\hline CS 141 & -111.4 & 1.342 & $19.29^{*}$ & 1.830 & -0.473 & 0.9534 \\
\hline \multicolumn{7}{|l|}{ ICSA $38 \times$} \\
\hline NR 71182-3 & $673.5^{*}$ & $-2.841^{*}$ & -11.70 & -0.075 & 0.110 & 1.8607 \\
\hline NR 71168-1 & $-756.5^{*}$ & 1.353 & -13.77 & $2.090^{* * *}$ & -3.072 & -0.8427 \\
\hline CS 54 & -57.9 & $3.603^{*}$ & $36.61^{*}$ & 0.501 & 0.927 & 0.6623 \\
\hline CS 95 & -479.3 & $2.898^{*}$ & -1.08 & -0.390 & -2.535 & -0.8838 \\
\hline Damougari & $1214.1^{*}$ & $-4.863^{*}$ & -11.31 & $-3.750^{*}$ & $5.137^{* * *}$ & -0.2043 \\
\hline \multicolumn{7}{|l|}{ ICSA $39 \times$} \\
\hline NR 71176-1 & -106.4 & 0.114 & $19.67^{*}$ & -1.995 & 2.855 & 0.9790 \\
\hline KSV 4-1 & 22.6 & 0.648 & $-33.78^{*}$ & -0.872 & -0.888 & -1.4488 \\
\hline CS 144 & $892.9^{*}$ & $1.742^{* *}$ & $-16.67^{* *}$ & $2.212^{* * *}$ & 0.456 & -0.4310 \\
\hline Damougari & $974.1^{*}$ & $-4.063^{*}$ & $-24.9^{*}$ & $-4.007^{*}$ & 3.349 & 0.5573 \\
\hline \multicolumn{7}{|l|}{$\operatorname{ICSA} 41 \times$} \\
\hline NR 71168-1 & $-551.5^{* *}$ & 0.034 & $-16.53^{* *}$ & $3.773^{*}$ & -1.488 & -0.7960 \\
\hline KSV 4-2 & 22.0 & $-2.508^{*}$ & 15.01 & 0.409 & -1.918 & -1.2332 \\
\hline CS 54 & -201.1 & $2.220^{*}$ & $30.04^{*}$ & $2.103^{* *}$ & -2.685 & -0.2727 \\
\hline CS 95 & -428.1 & $3.314^{*}$ & -0.29 & 0.515 & -3.256 & -0.8804 \\
\hline Damougari & -113.0 & -1.363 & $23.61^{* *}$ & $-3.062^{*}$ & -1.232 & -1.2343 \\
\hline \multicolumn{7}{|l|}{ ICSA $902 N G \times$} \\
\hline KSV 4-2 & $677.7^{*}$ & $-3.458^{*}$ & 11.73 & $-2.446^{* *}$ & 4.486 & 0.6834 \\
\hline CS 54 & -412.9 & $4.270^{*}$ & $20.89^{*}$ & 1.506 & $-5.968^{* *}$ & 0.7773 \\
\hline CS 95 & -187.0 & $2.131^{*}$ & 10.63 & 0.495 & -3.058 & -0.0104 \\
\hline CS 141 & $-552.1^{* * *}$ & 1.226 & $-19.68^{*}$ & 1.582 & -4.742 & -1.5999 \\
\hline Damougari & $619.9^{* *}$ & $-3.380^{*}$ & -5.74 & $-3.040^{*}$ & $5.378^{* * *}$ & 0.5857 \\
\hline S.E. & 271.9 & 0.887 & 7.25 & 0.993 & 2.291 & 0.8661 \\
\hline
\end{tabular}

${ }^{*}$ Significant at 0.01 probability levels.

** Significant at 0.05 probability levels. 
parents, showing the importance of non-additive interaction due to large or minor gene effects in particular hybrid combination. The estimates of SCA effects of selected crosses are presented in Table 5. The magnitude of SCA estimates varied among crosses. High positive SCA estimates for grain yield were obtained from the following crosses: ICSA $38 \times$ NR 71182-3, ICSA $38 \times$ Damougari, ICSA $39 \times$ Damougari, ICSA $902 \times$ KSV4- 2 and ICSA $902 \times$ Damougari. It was observed that large positive SCA effect for grain yield was obtained by the cross ICSA $902 \times$ Damougari and at least one parent of this mating had positive GCA effect for this trait. ICSA $39 \times$ Damougari had the second highest significant positive SCA effect for grain yield and both parents of this mating had low or no significant GCA estimates. This suggests that SCA effect could result from mating any combination of high and low GCA parents.

As concerns days to anthesis, 14 crosses showed significant SCA effect in a desirable direction. With respect to inflorescence length, eleven crosses showed positive significant SCA effects. For threshing percentage, some crosses showed significant negative SCA effects. Data shown in Table 5 for grain yield values of $s_{i j}$ are predominantly negative, a strong indication of hybrid positive heterosis.

The crosses that recorded high SCA effects, coupled with high per se performance for yield and its components involved either one or both of the parents with good GCA for the trait being considered. The parents that were the best general combiners did not always produce the best hybrid combinations. This may have been expected because of lack of higher order additive interactions. This difficulty in predicting the productivity level of the hybrid, on the basis of GCA alone should necessitate testing of specific male-female combination. However, in all high yielding hybrids at least a good general combiner was involved. According to Marilia et al. (2001), the SCA effect alone has limited value for parental choice in breeding programs. The SCA effects should be used in combination with other parameters, such as hybrid means and the GCA of the respective parents. Thus, hybrid combination with high mean, with favorable SCA estimate and involving at least one of the parents with high GCA, would tend to increase the concentration of favorable alleles; an appreciable situation to any breeder.
The results indicated that genetic variability among the parental lines exists for the various traits studied. Some of this genetic variation appears to be additive in nature. A more definitive separation of additive, dominance and non-additive genetic effects for these traits requires evaluation of additional sets of germplasm. Low GCA and SCA effects were obtained for some parents and their crosses. These traits can be improved through breeding procedure using a range of different intra-population and inter-population selection procedures. Although less than definitive, results from the current study indicate that most of the hybrids obtained from crosses among these populations would be expected to perform better than open-pollinated cultivars, and that in hybrid breeding procedures, testing of parent lines for general combining ability should be supplemented by the evaluation of individual $F_{1}$ hybrids for specific combining ability. The variability among plant material should make it possible to develop hybrids for diverse environmental conditions without sacrificing yield. Combining ability information from this study will be useful for sorghum breeders who are using landraces or intend to use them for developing adapted high yielding hybrids.

\section{References}

Axtell, J., Kapran, I., Ibrahim, Y., Ejeta, G., Andrews, D.J., 1999. Heterosis in sorghum and pearl millet. In: Proceedings of the Genetic and Exploitation of Heterosis in Crops. ASA-CSSASSSA, WI, USA, pp. 375-386.

Baker, R.J., 1978. Issues in diallel analysis. Crop Sci. 18, 533-536.

Beil, G.M., Atkins, R.E., 1967. Estimates of general and specific combining ability in $\mathrm{F}_{1}$ hybrids for grain yield and its components in grain sorghum, Sorghum vulgare. Pers. Crop Sci. 7, 225-228.

Comstock, R.E., Robinson, H.F., 1952. Estimation of average dominance of genes. In: Gowen, J.W. (Ed.), Heterosis. Iowa State College Press, Ames, IA, pp. 494-516.

Cox, D.J., Frey, K.J., 1984. Combining ability and the selection of parents for interspecific oat mating. Crop Sci. 24, 963-967.

Cruz, C.D., Regazzi, A.J., 1994. Modelos biometricos aplicados ao melhoramento genetico. Universidade Federal de Viçosa, Imprensa Universitaria, Viçosa, Minas Gerais, Brazil.

Dudley, J.W., Moll, R.H., 1969. Interpretation and use of estimates of heritability and genetic variances in plant breeding. Crop Sci. 9, 257-262.

Falconer, D.S., 1989. Introduction to Quantitative Genetic, 3rd ed. Longman, Essex, UK, pp. 275-276.

Food and Agriculture Organization of the United Nation, 1997. FAO Year book. Statistics series No. 135. Food and Agriculture Organization of the United Nation, Rome. 
Goyal, S.N., Kumar, S., 1991. Combining ability for yield component and oil content in sesame. Indian J. Genet. Plant Breed. 51, 311-314.

House, L.R., 1995. Sorghum: one of the world's great cereals. Afr. Crop Sci. J. 3, 135-142.

IBPGR/ICRISAT, 1993. Description for Sorghum. IBPGR Secretariat, FAO, Rome, Italy, pp. 1-26.

Kempthorne, O., 1957. An Introduction to Genetic Statistics, 1st ed. Wiley, New York, USA, pp. 458-471.

Kirby, J.S., Atkins, R.E., 1968. Heterosis response for vegetative and mature plant characters in grain sorghum, Sorghum bicolor (L.). Moench. Crop Sci. 8, 335-339.

Liang, G.H., Walter, T.L., 1968. Heritability estimates and gene effect for agronomic traits in sorghum, Sorghum vulgare. Pers. Crop Sci. 8, 77-83.

Malm, N.R., 1968. Exotic germplasm use in grain sorghum improvement. Crop Sci. 8, 295-298.

Marilia, C.F., Servio, T.C., Valter, O.R., Clibas, V., Siu, T.M., 2001. Combining ability for nodulation in common bean (Phaseolus vulgaris L.) genotypes from Andean and Middle American gene pools. Euphytica 118, 265-270.

Maunder, A.B., 1992. Identification of useful germplasm for practical plant breeding programs. In: Stalker, H.T., Murphy, J.P. (Eds.), Plant Breeding in the 1990's. CAB International, Wallingford, UK, pp. 147-149.
Niehaus, M.H., Pickett, M.H., 1966. Heterosis and combining ability in a diallel cross in Sorghum vulgare. Pers. Crop Sci. 6, 33-36.

Paisan, L., Atkins, R.E., 1977. Estimates of combining ability and heterosis in converted exotic sorghum. Crop Sci. 17, 47-50.

Palmer, G.H., 1992. Sorghum—food beverage and brewing potentials. Process Biochem. 27, 145-153.

Rojas, B.A., Sprague, G.F., 1952. A comparison of variance components in corn yield traits. III. General and specific combining ability and their interaction with locations and years. Agron. J. 44, 462-466.

SAS Institute, 1989. SAS User's Guide: Statistics. Version 5 ed. SAS Institute, Cary, NC.

Shantharam, S., 1995. The importance of biosafety in the deployment of private transgenic sorghums in the environment. Afr. Crop Sci. J. 3, 131-133.

Singh, R.K., Chaudhary, B.D., 1977. Biometrical Methods in Quantitative Genetic Analysis. Kalyani Publishers, Ludhiana, New Delhi, p. 318.

USDA, 1997. Time series data base. Economic Research Service, USDA, Washington.

Windmeijer, P.N., Andriesse, W., 1993. Inland valleys in West Africa: an agro-ecological characterization of rice-growing environments, Publication 52. International Institute for Land Reclamation and Improvement, Wageningen, The Netherlands. 